\title{
Does Imidacloprid Reduce Defoliation by Japanese Beetles on Linden for More Than One Growing Season?
}

\author{
Steven Frank, Robert Ahern, and Michael J. Raupp
}

\begin{abstract}
Laboratory feeding trials confirmed that leaves from little-leaf linden treated with imidacloprid were eaten by Japanese beetles far less than those from untreated trees. Field studies revealed that soil applications of imidacloprid significantly reduced the degree of severe defoliation caused by Japanese beetles in the year that the insecticide was applied and also in the next year. These findings indicate that imidacloprid is a useful tool for arborists in reducing defoliation by this important pest.
\end{abstract}

Key Words. Defoliation; feeding deterrence; imidacloprid; IPM; Japanese beetle; linden; plant health care.

Lindens, Tilia spp., are one of the most commonly planted street trees in eastern North America, where they enhance the aesthetic quality of life in cities (Raupp et al. 2006). However, lindens are subject to attack by a variety of insect pests, not the least of which is the Japanese beetle, Popillia japonica. Japanese beetles feed on more than 300 species of plants and, among shade trees, lindens are favored hosts (Held 2004). Although resistance has been noted in some species of lindens (Held 2004), insecticides remain a primary tactic for controlling this pest (Potter and Held 2002).

Imidacloprid was the first neonicotinoid insecticide to be introduced to the arboricultural market and it is still one of the most popular materials applied in landscapes because of its range of activity against key pests, including leaf beetles (Sclar and Cranshaw 1996; Lawson and Dahlsten 2003), lace bugs (Gill et al. 1999), aphids (Sclar and Cranshaw 1996), scales (Sclar and Cranshaw 1996; Gill and Reeser 1999), psyllids (Young 2002), adelgids (Stewart and Horner 1994; Doccola et al. 2003; Webb et al. 2003), periodical cicadas (Ahern et al. 2005), flatheaded borers (Herms 2003), and leafminers (d'Eustachio and Raupp 2001). However, a recent study by Hubbard and Potter (2006) found that imidacloprid provided poor control of Calico scale, Eulecanium cerasorum, on landscape trees. Although systemic products have been used against a variety of insect pests, there are no published accounts of the efficacy of neonicotinoids for reducing injury caused by feeding of the Japanese beetle.

It is the goal of this study to determine the efficacy of imidacloprid in reducing damage caused by Japanese beetles to little-leafed linden, Tilia cordata, as well as whether imidacloprid could protect feeding by Japanese beetles beyond the initial year of application. Most studies of imidacloprid efficacy have focused on its toxicity within a time scale of weeks to months after application. Notable exceptions include the work of Sclar and Cranshaw (1996), Webb et al. (2003), and Szczepaniec and Raupp (2007).

Sclar and Cranshaw (1996) found imidacloprid to be lethal to European elm scale, Gossyparia spuria, 15 months after soil injections of imidacloprid. Imidacloprid drenches were found to be lethal against elm leaf beetle, Xanthogaleruca luteola, for more than 12 months (Sclar and Cranshaw 1996). Webb et al. (2003) found Eastern Hemlocks, Tsuga canadensis, to be free of hemlock woolly adelgid, Adelges tsugae, 816 days after the application of imidacloprid to the soil despite the fact that trees infested with adelgids were nearby in the same landscape planting. Cotoneasters grown in containers demonstrated toxicity to hawthorn lace bugs, Corythuca cydoniae, for 800 days after the application of imidacloprid to the soil Szczepaniec and Raupp (2007).

In addition to elucidating temporal aspects of imidacloprid efficacy, a study was designed to determine if the application of imidacloprid affected the pattern of feeding of Japanese beetles within the canopy of linden trees. Rowe and Potter (1996) and Potter (1998) noted a clear pattern of vertical stratification of damage caused by feeding of Japanese beetles. They found upper-canopy, sun-exposed leaves to be more heavily damaged by Japanese beetles than lowercanopy, shaded ones.

\section{MATERIALS AND METHODS}

Research was conducted at the University of Maryland Turfgrass Research Facility, College Park, Maryland, U.S., during the summers of 2004, 2005, and 2006. Twenty little-leaf linden, $T$. cordata, trees were used. Trees were planted in 2001 
and at the time of insecticide application in 2004, they were uniformly $3 \mathrm{~m}(9.9 \mathrm{ft})$ tall and $7 \mathrm{~cm}$ (2.8 in) diameter breast height (DBH). At the end of the study in 2006, trees were approximately $4 \mathrm{~m}(13.2 \mathrm{ft})$ tall and $9 \mathrm{~cm}$ (3.6 in) DBH. Trees were surrounded by several acres of turfgrass that served as a source for Japanese beetles that readily colonized and consumed leaves of the study trees.

Each tree was randomly assigned to one of two treatments to establish ten replicates of each treatment. Treatments included the application of imidacloprid (Merit ${ }^{\circledR} 75 \mathrm{WP}$; Bayer Corp., Kansas City, MO) and remaining trees left untreated. Trees in the imidacloprid treatment received $2 \mathrm{~g}(0.07 \mathrm{oz})$ of imidacloprid per $2.54 \mathrm{~cm}$ (1.02 in) DBH in $3.8 \mathrm{~L}$ (1 gal) of water. Imidacloprid was mixed in a plastic pail and applied as a soil drench around the circumference of the tree at the root collar within $1 \mathrm{~m}$ ( $3.3 \mathrm{ft})$ of the trunk. Application took place on 7 May 2004, approximately 1 month before the appearance of Japanese beetles.

\section{Feeding Deterrence}

It was the goal of this study to determine if leaves from trees treated with imidacloprid were consumed less than leaves from untreated plants. To assess this, we removed single leaves of the same phonological age, specifically the first fully expanded leaf on a branch with an active meristem, from each treated and each untreated tree. The area of each leaf was measured with a Li-Cor ${ }^{\circledR}$ LI-3100C area meter (LICOR Biosciences, Lincoln, NE). The leaf was placed in a large Petri plate lined with moistened filter paper. Japanese beetles were collected from untreated linden trees at the study site. A single beetle was randomly assigned to a Petri plate containing either a treated or untreated leaf and allowed to feed for $24 \mathrm{hr}$. At the end of the feeding interval, beetles were removed and the leaf area was once again measured. The amount of leaf area consumed by each beetle was estimated by subtracting the leaf area remaining from the leaf area at the start of the assay.

\section{Defoliation}

We assessed the ability of imidacloprid to mitigate defoliation severe enough to reduce the aesthetic quality of lindens growing in a landscape as perceived by a homeowner or urban forester. In a previous study Raupp et al. (1988) demonstrated a direct relationship between levels of defoliation and perception of injury to arborvitaes attacked by the evergreen bagworm, Thyridopteryx ephemeraeformis. When defoliation by bagworms reached $50 \%$, more than $95 \%$ of people agreed that the plants were damaged and that control was warranted. This and other studies such as those by Sadof and Raupp (1987), Coffelt and Shultz (1990), and Sadof and Raupp (1997) confirmed the finding that 50\% defoliation was regarded as damaged by than $90 \%$ of people surveyed. To provide an unambiguous definition of defoliation, we chose
$50 \%$ or more defoliation of an individual leaf to be an indicator of severe damage.

To estimate the efficacy of imidacloprid in preventing severe damage, we examined 80 leaves on each tree treated with imidacloprid and those untreated. At each of four cardinal points, north, east, south, and west, we examined one shoot in the upper half of the tree and one shoot in the lower half of the tree. Ten leaves were examined on each shoot and the number of leaves recorded with $50 \%$ or more of their leaf area missing. Defoliation was quantified in the second week of August in 2004, 2005, and 2006 when feeding by Japanese beetles was nearly complete. The response variable used for our statistical analysis was the proportion of leaves severely damaged. Severe damage was expressed as the proportion of leaves in a sample of ten that sustained $50 \%$ or more defoliation.

\section{Statistical Analyses}

Data from the feeding deterrence assays were not normal and could not be normalized through transformation. Variances were not homogeneous. Therefore, amounts of leaf area consumed by beetles eating leaves from treated and untreated trees were compared with a Kruskal-Wallis nonparametric analysis of variance (Zar 1999; Statistix ${ }^{\circledR}$ Analytical Software, Tallahassee, FL).

We studied not only the effect of imidacloprid on Japanese beetle feeding, but also if the application of imidacloprid affected the pattern of damage caused by Japanese beetles as they fed. These data were analyzed as a split, split plot with cardinal direction and leaf position (height) in the canopy as subplots. Proportional data were transformed with the arcsine square root to satisfy the assumptions for analysis of variance as suggested by Zar (1999). The proportions of severely damaged leaves per tree were analyzed with the general linear models procedure (Statistix Analytical Software) in 2004 and 2005. A Tukey test was used to separate treatment means following the analysis of variance (Statistix Analytical Software). In 2006, Japanese beetle populations were very low at our study site and imidacloprid treatments could not be examined for interactive effects with tree height and cardinal direction. We could examine only the direct effect of imidacloprid on severe damage caused by Japanese beetle. Data collected in 2006 did not meet assumptions for analysis of variance and transformations of these data failed correction for normality. Therefore, differences in amounts of severe damage on treated and untreated trees were compared with a Kruskal-Wallis nonparametric analysis of variance (Zar 1999; Statistix Analytical Software).

\section{RESULTS AND DISCUSSION Feeding Deterrence}

Japanese beetles consumed significantly less leaf tissue on leaves from trees treated with imidacloprid $(P<0.0001$, 
$\left.\chi^{2}=15.25\right)$. The average leaf area consumed on treated leaves was $0.003 \pm 0.002 \mathrm{~cm}^{2}$ and the leaf area eaten on untreated leaves was $49.1 \pm 0.75 \mathrm{~cm}^{2}$. In addition to dramatic reductions in feeding, half of the beetles that consumed leaves from trees treated with imidacloprid died or exhibited signs of intoxication such as trembling, lack of coordination, and, finally, cessation of movement and death. These symptoms are common for insects intoxicated with imidacloprid (Suchail et al. 2001). No beetles that ate leaves from untreated trees died during the course of the assay.

\section{Defoliation in the Field}

As a result of dramatically different levels of Japanese beetle abundance and associated damage during all 3 years, we analyzed data from each year independently. The application of imidacloprid significantly reduced the proportion of severely damaged leaves in 2004 and 2005 (2004, $P<0.0002, \mathrm{~F}_{1,9}=$ $37.16 ; 2005, P<0.0001, \mathrm{~F}_{1,9}=40.09$ ). In 2004, the proportions of severely damaged, as measured by leaves with $50 \%$ or more of their area missing, leaves on treated trees and untreated leaves were $0.07 \pm 0.01$ and $0.23 \pm 0.03$, respectively. In 2005, the proportion of severely damaged leaves on treated and untreated trees were $0.28 \pm 0.03$ and $0.74 \pm 0.03$, respectively. Populations of Japanese beetles during 2006 were very low and the resultant damage was negligible. Most leaves had less than 5\% leaf surface area damaged by Japanese beetles on treated and control trees. The proportion of severely damaged leaves did not differ significantly between those treated with imidacloprid and those untreated $(P<0.55$, $\left.\chi^{2}=0.34\right)$. The proportions of severely damaged leaves on treated and untreated trees were $0.02 \pm 0.001$ and $0.02 \pm$ 0.001 , respectively.

In 2004, there was no significant interaction between the application of imidacloprid and the height of leaves in the canopy of the tree. This indicates that defoliation related to feeding by Japanese beetles was consistent between high- and low-canopy branches within each insecticide treatment. However, in 2005, there was a significant insecticidal treatment by height interaction $\left(P<0.0003, \mathrm{~F}_{1,72}=14.63\right)$ (Figure 1). In 2005 , leaves in the lower canopy of trees treated with imidacloprid sustained very low levels of injury, whereas approximately $50 \%$ of leaves in the upper canopy of treated trees were severely damaged.

In both years, defoliation was significantly affected by the height of the leaves in the tree canopy with a clear pattern for greater levels of defoliation in the upper canopy (2004, $P<$ $\left.0.0001, \mathrm{~F}_{1,72}=97.73 ; 2005, P<0.0001, \mathrm{~F}_{1,72}=34.87\right)$ (Figure 1). This result supports and confirms observations made previously by Fleming (1972) and Rowe and Potter (1996). Rowe and Potter (1996) suggested that Japanese beetles aggregate in the upper canopy of trees as they orient to the silhouette of their hosts during colonization. Once feed-

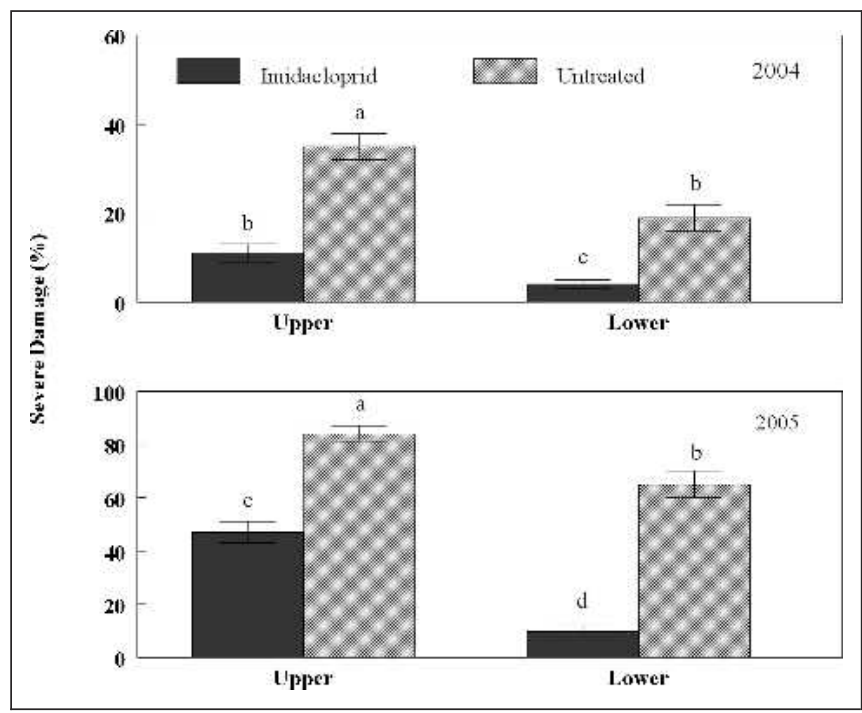

Figure 1. Percent of leaves severely damaged by Japanese beetles in 2004 and 2005 in the upper and lower canopies of Tilia cordata trees treated with imidacloprid and untreated controls. Bars represent means and vertical lines represent standard errors. Within each year, means that share the same letter do not differ by Tukey test $(P<0.05)$.

ing begins, the release of floral and fruit-like volatile compounds such as linalool and aliphatic esters attracts everincreasing numbers of beetles to the upper canopy of the tree (Loughrin et al. 1996, 1997).

An interaction between direction and insecticidal treatment $\left(P<0.016, \mathrm{~F}_{3,54}=3.76\right)$ governed the degree of defoliation in 2004 (Figure 2). Defoliation was suppressed and similar at all cardinal points on trees treated with imidacloprid, but severe defoliation was more common on western exposures than on northern ones. No such pattern was observed in 2005 when levels of defoliation exceeded $74 \%$ and the degree of defoliation was uniformly distributed around the canopies of both treated and untreated trees (Figure 2). It is not clear why defoliation was more intense on western exposures and less so on northern or other exposures. Beetles may have initially colonized the western sides of trees from surrounding habitats. Feeding would increase volatile release and attract other beetles to these portions of the trees (Rowe and Potter 1996; Loughrin et al. 1996, 1997).

During both 2004 and 2005, we observed dead beetles beneath the canopies of trees treated with imidacloprid but not beneath untreated trees. Moreover, Japanese beetles were observed on the foliage or treated trees expressing symptoms of poisoning, including trembling, uncoordinated movement, and arrested movement. Soil applications of imidacloprid reduced defoliation in the year of application and at least 1 year thereafter. 


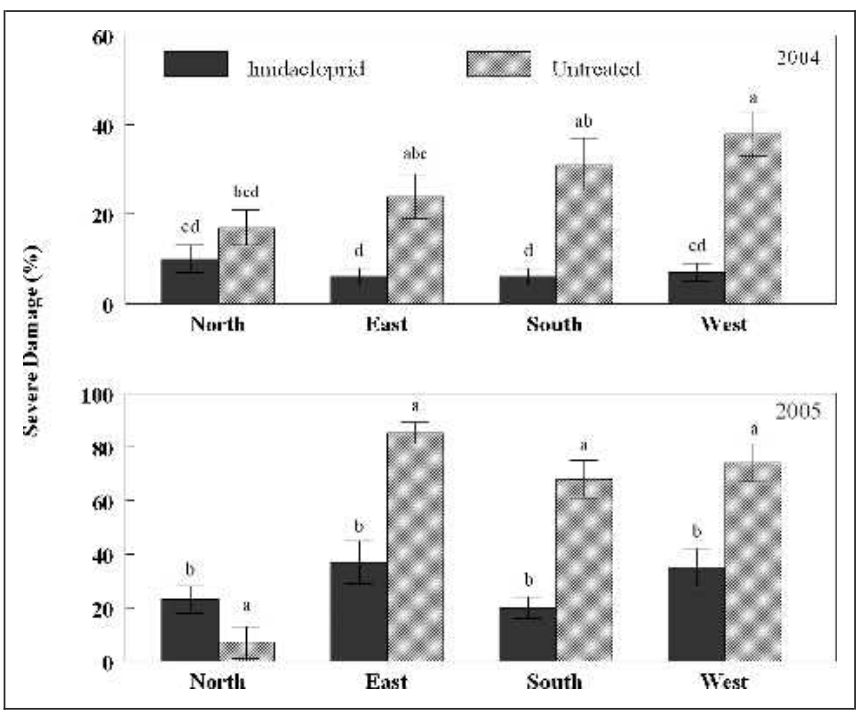

Figure 2. Percent of leaves severely damaged by Japanese beetles in $\mathbf{2 0 0 4}$ and $\mathbf{2 0 0 5}$ at four cardinal points of Tilia cordata trees treated with imidacloprid and untreated controls. Bars represent means and vertical lines represent standard errors. Within each year, means that share the same letter do not differ by a Tukey test $(P<$ 0.05).

\section{IMPLICATIONS FOR ARBORICULTURE}

Imidacloprid can significantly reduce the amount of feeding associated with Japanese beetles. Laboratory feeding trials clearly showed that Japanese beetles consumed significantly less leaf tissue when trees were treated with imidacloprid. Field studies revealed that severe defoliation caused by the feeding of Japanese beetles was greatly reduced by the application of imidacloprid. This reduction was seen during the year of application in which severe defoliation on treated trees was approximately $70 \%$ lower than on untreated ones. In the next year, when Japanese beetles were more abundant and defoliation was generally greater, imidacloprid continued to provide a $62 \%$ reduction in severe defoliation. This extended period of protection should reduce the necessity for multiple insecticide applications for management of Japanese beetles on lindens and, likely, other amenity trees attacked by this important pest.

Acknowledgments. We thank Chris Tierno and Kate Laskowski for assistance with the collection of data. We also thank Bayer Environmental Science for providing the imidacloprid used in the study.

\section{LITERATURE CITED}

Ahern, R.G., S.D. Frank, and M.J. Raupp. 2005. Comparison of exclusion and imidacloprid for reduction of oviposition damage to young trees by periodical cicadas (Homoptera: Cicadidae). Journal of Economic Entomology 98: 2133-2136.

Coffelt, M.A., and P.B. Shultz. 1990. Development of an aesthetic injury level to decrease pesticide use against orangestriped oakworm (Lepidoptera: Saturniidae) in an urban pest management project. Journal of Economic Entomology 83:2044-2049.

d'Eustachio, G., and M.J. Raupp. 2001. Application of systemic insecticides in relation to boxwood leafminer's life history. Journal of Arboriculture 27:255-262.

Doccola, J.J., P.M. Wild, I. Ramaswamy, P. Castillo, and C. Taylor. 2003. Efficacy of Arborjet viper microinjections in the management of hemlock wooly adelgid. Journal of Arboriculture 29:327-330.

Fleming, W.E. 1972. Biology of the Japanese Beetle. USDA Technical Bulletin 1449. United States Department of Agriculture, Washington, DC. 129 pp.

Gill, S., D.K. Jefferson, R.M. Reeser, and M.J. Raupp. 1999. Use of soil and trunk injection of systemic insecticides to control lace bug on hawthorn. Journal of Arboriculture 25:38-41.

Gill, S., and R. Reeser. 1999. Wax scale: Mild winters = big problems. Groundwork April:13-15.

Held, D. 2004. Relative susceptibility of woody landscape plants to Japanese beetle (Coleoptera: Scarabaeidae). Journal of Arboriculture 30:328-335.

Herms, D.A. 2003. The enemy within: Understanding the biology and management of borers. Tree Care Industry. 14:8-17.

Hubbard, J.L., and D.A. Potter. 2006. Managing calico scale (Hemiptera: Coccidae) infestations on landscape trees. Journal of Arboriculture 32:138-147.

Lawson, A.B., and D.L. Dahlsten. 2003. Evaluation of systemic insecticides as a treatment option in Integrated Pest Management of the Elm Leaf Beetle, Xanthogaleruca luteola (Muller) (Coleoptera: Chrysomelidae). Journal of Economic Entomology 96:1455-1462.

Loughrin, J.H., D.A. Potter, T.R. Hamilton-Kemp, and M.E. Byers. 1996. Role of feeding-induced plant volatiles in aggregative behavior of the Japanese beetle (Coleoptera: Scarabaeidae). Environmental Entomology 25:11881191.

1997. Response of Japanese beetles (Coleoptera: Scarabaeidae) to leaf volatiles of susceptible and resistant maple species. Environmental Entomology 26:334-342.

Potter, D.A. 1998. Destructive Turfgrass Insects. Biology, Diagnosis, and Control. Ann Arbor Press, Chelsea, MI. $344 \mathrm{pp}$.

Potter, D.A., and D.W. Held. 2002. Biology and management 
of Japanese beetle. Annual Review of Entomology 47: 175-205.

Raupp, M.J., A. Buckelew Cumming, and E.C. Raupp. 2006. Street tree diversity in Eastern North America and its potential for tree loss to exotic borers. Arboriculture and Urban Forestry 32:297-304.

Raupp, M.J., J.A. Davidson, C.S. Koehler, C.S. Sadof, and K. Reichelderfer. 1988. Decision-making considerations for aesthetic damage caused by pests. Bulletin of the Entomological Society of America 34:27-32.

Rowe, W.J. II, and D.A. Potter. 1996. Vertical stratification of feeding by Japanese beetles within linden tree canopies: Selective foraging or height per se? Oecologia 108: 459-466.

Sadof, C.S., and M.J. Raupp. 1987. Consumer attitudes toward the defoliation of American arborvitae, Thuja occidentalis by bagworm, Thyridopteryx ephemeraeformis. Journal of Environmental Horticulture 5:164-166.

. 1997. Aesthetic thresholds and their development, pp. 203-226. In L.G. Higley and L.P. Pedigo (Eds.). Economic Thresholds for Integrated Pest Management. University of Nebraska Press, Lincoln, NE. 327 pp.

Sclar, D.C., and W.S. Cranshaw. 1996. Evaluation of new systemic insecticides for elm insect control. Journal of Environmental Horticulture 14:22-26.

Stewart, V.B., and T.A. Horner. 1994. Control of hemlock wooly adelgid using soil injections of systemic insecticides. Journal of Arboriculture 20:287-289.

Suchail, S., D. Guez, and L.P. Belzunces. 2001. Discrepancy between acute and chronic toxicity induced by imidacloprid and its metabolites in Apis mellifera. Environmental Toxicology and Chemistry 20:2482-2486.

Szczepaniec, A., and M.J. Raupp. 2007. Residual toxicity of imidacloprid to hawthorn lace bug, Corythuca cydoniae, feeding on cotoneasters in landscapes and containers. Journal of Environmental Horticulture 25:43-46.

Webb, R.A., J.R. Frank, and M.J. Raupp. 2003. Recovery of eastern hemlock from attack by hemlock woolly adelgid following treatment with imidacloprid. Journal of Arboriculture 29:298-302.

Young, L.C. 2002. The efficacy of micro-injected imidacloprid and oxydemeton-methyl on red gum eucalyptus trees (Eucalyptus camaldulensis) infested with red gum lerp psyllid (Glycaspis brimblecombei). Journal of Arboriculture 28:144-147.

Zar, J. 1999. Biostatistical Analysis. Prentice Hall, Upper Saddle River, NJ. 931 pp.
Steven Frank

Research Assistant

Department of Entomology

4112 Plant Sciences

University of Maryland

College Park, MD 20742, U.S.

Robert Ahern

Research Assistant

Department of Entomology

4112 Plant Sciences

University of Maryland

College Park, MD 20742, U.S.

Michael J. Raupp (corresponding author)

Professor of Entomology

Department of Entomology

4112 Plant Sciences

University of Maryland

College Park, MD 20742, U.S.

mraupp@umd.edu

Résumé. Les essais alimentaires en laboratoire confirment que les feuilles du tilleul à petites feuilles traitées avec l'imidacloprid étaient moins dévorées par les scolytes japonais que celle d'arbres non traités. Les études sur le terrain ont révélé que les applications sur le sol d'imidacloprid ont significativement diminué le degré de sévérité de la défoliation causée par les scolytes japonais dans l'année où l'insecticide a été appliqué ainsi que l'année subséquente. Ces découvertes indiquent que l'imidacloprid constitue un outil utile pour les arboriculteurs afin de réduire la défoliation par cet important parasite.

Zusammenfassung. Laborfütterungsversuche bestätigten, dass Blätter der Winterlinde, die mit Imidacloprid behandelt waren, weniger von Japan-Käfern gefressen wurden als die von unbehandelten Bäumen. Feldstudien ergaben, dass Bodenapplikationen mit Imidacloprid die Schwere der Entlaubung durch den Japan-Käfer in dem Jahr der Applikation und in den Folgejahren reduziert. Diese Ergebnisse zeigen, dass Imidacloprid ein nützliches Werkzeug für $\mathrm{Ar}$ boristen bei der Bekämpfung dieses bedeutenden Schädlings ist.

Resumen. Ensayos de laboratorio confirmaron que las hojas de tilo tratadas con imidacloprid fueron consumidas mucho menos por escarabajos japoneses que las de árboles no tratados. Estudios de campo revelaron que las aplicaciones al suelo de imidacloprid redujeron significativamente el grado de defoliación severa causada por lo escarabajos en el año en que el insecticida fue aplicado, y también en el siguiente. Estos hallazgos indican que imidacloprid es una herramienta útil para los arboristas para reducir la defoliación por esta importante plaga. 